\title{
PROPOLIS EFFECT ON STREPTOZOTOCIN-INDUCED DIABETIC RATS
}

\author{
Sartori DRS (1), Kawakami CL (1), Orsatti CL (2), Sforcin JM (2)
}

(1) Department of Physiology, Botucatu Biosciences Institute, São Paulo State University, UNESP, Botucatu, São Paulo State, Brazil; (2) Department of Microbiology and Immunology, Botucatu Biosciences Institute, São Paulo State University, UNESP, Botucatu, São Paulo State, Brazil.

\begin{abstract}
Propolis is one of the hive products that has been used extensively in folk medicine, due to its several biological and pharmacological properties. Besides, propolis-containing products have been intensely marketed by the pharmaceutical industry and health-food stores. This work was carried out in order to investigate whether propolis treatment could revert the metabolic alterations of streptozotocininduced diabetic rats. Animals were kept in metabolic cages and diabetes was induced by a single dose of streptozotocin (35 mg/kg, IV). After a week, rats with glycemia higher than $230 \mathrm{mg} / \mathrm{dL}$ were divided into two groups and treated with ethanolic extract of propolis (10 and $90 \mathrm{mg} / \mathrm{kg}$, PO) for seven days. Glycemia and free fatty acids were determined, as well as food and water intake, body weight and urine volume were registered weekly. Data showed no significant differences in the analyzed variables. Based on these results, one may conclude that propolis had no effects after diabetes establishment, in our conditions assays. Further assays with different concentrations of propolis and periods of administration should be carried out in order to evaluate its therapeutic potential in this disease.
\end{abstract}

KEY WORDS: Brazilian propolis, diabetes, glucose, free fatty acids.

CONFLICTS OF INTEREST: There is no conflict.

\section{CORRESPONDENCE TO:}

JOSÉ MAURÍCIO SFORCIN, Departamento de Microbiologia e Imunologia, Instituto de Biociências, UNESP, Botucatu, SP, 18618-000, Brasil. Fax: +55 14 3815-3744. Email: sforcin@ibb.unesp.br. 


\section{INTRODUCTION}

Propolis is a resinous material collected by bees from buds and plant exudates, which is mixed with products of their salivary glands and wax. The use of propolis dates back to ancient times, and it has been utilized as a medicine in several parts of the world, both for internal or external use. Nowadays, propolis has attracted researchers' interest due to its several therapeutic activities, such as immunomodulatory, antitumor, antimicrobial, anti-inflammatory and antioxidant effects, among others (1). After its administration to animals or to humans propolis does not appear to present side effects $(2,3)$.

The chemical composition of this substance is very complex and depends on the source plant. The main vegetal source of propolis in Botucatu, São Paulo State, Brazil, is Baccharis dracunculifolia DC., followed by Eucalyptus citriodora Hook and Araucaria angustifolia (Bert.) O. Kuntze (4).

Diabetes mellitus is a metabolic disorder characterized by hyperglycemia and glycosuria due to absolute or relative insulin deficiency (type 1 and type 2, respectively). The hyperglycemia is resultant of reduced entry of glucose into various tissues and increased liberation of glucose into the circulation from the liver. In addition, there is glycosuria because the renal capacity for glucose reabsorption is exceeded. The excess of glucose outside the cells in diabetes contrasts with the intracellular deficit. Glucose catabolism is normally a major source of energy for cellular process, and in diabetes, energy requirements can be met by drawing on protein and fat reserves. Mechanisms are activated that greatly increase the catabolism of protein and fat, and one of the consequences of increased fat catabolism is ketosis and development of diabetic acidosis, specially in diabetes type $1(5,6)$.

Streptozotocin (STZ) is an established diabetogenic agent in animal models, which induces insulin deficiency due to its selective pancreatic $\beta$-cell cytotoxicity caused by DNA alkylation and nitric oxide (NO) generation $(7,8)$.

Since in the recent years many works have been carried out aiming to investigate propolis effects in several pathologic conditions, this work evaluated propolis action on diabetic rats, determining glucose and free fatty acids (FFA) levels before and after propolis treatment, as well as water and food intake, urine flow and body weight of the animals. 


\section{MATERIAL AND METHODS}

\section{Propolis Sample}

Propolis was collected in the Beekeeping Section, UNESP, Botucatu, Brazil. It was produced by Africanized honeybees (Apis mellifera, L.) and deposited on plastic nets. Nets were taken and frozen to promote propolis removal. Afterwards, propolis was ground and added to solution to prepare $30 \%$ ethanolic extracts (30 $\mathrm{g}$ of propolis added to a $70 \%$ ethanol solution totaling $100 \mathrm{~mL}$ ), in the absence of bright light, at room temperature, and shaken moderately. After a week, extracts were filtered and the dry weight of the extracts was calculated $(120 \mathrm{mg} / \mathrm{mL})(9)$.

\section{Animal Care and Experimental Protocol}

Male Wistar rats weighing $220 \mathrm{~g}$ were randomly divided into two groups $(n=12)$ and had free access to standard rodent chow pellets and water ad libitum during the experimental period. Rats were kept in the Department of Physiology at $21^{\circ} \mathrm{C}$ under a 12-hour light/dark cycle. All animal procedures were done in accordance with Ethical Principles in Animal Research adopted by Brazilian College of Animal Experimentation.

Normal rats were kept into metabolic cages for seven days before the experiments and were considered as control. After 14 to16 hours of fasting, blood samples were collected on day 0 .

STZ was dissolved in sodium citrate buffer $0.01 \mathrm{M}(\mathrm{pH}=4.5)$ and administered at a single dose $(35 \mathrm{mg} / \mathrm{kg})$ into the tail vein to both groups. Animals with a concentration of more than $230 \mathrm{mg} / \mathrm{dL}$ were classified as diabetics (10). Rats were observed from day 0 to day 7 , in order to observe diabetes establishment.

From day 7 to day 14 , diabetic rats were treated with ethanolic extract of propolis $(0.4$ $\mathrm{mL}, \mathrm{PO}$, once a day) in two different concentrations previously standardized by our group: 10 and $90 \mathrm{mg} / \mathrm{kg}$ (P10 and P90, respectively). After day 14, animals were observed till day 21.

\section{Glucose and Free Fatty Acids Determination}

Blood samples were obtained by tail vein puncture before and after of STZ administration (days 0, 7, 14 and 21). Plasma FFA and blood glucose were determined by classical methods, respectively $(11,12)$. 


\section{Diabetic-Related Measurements}

Chow and water intake, and urine volume were registered daily. Body weight was recorded before blood collection every week.

\section{Statistical Analysis}

Analysis of variance (ANOVA) followed by Tukey test were employed. Data are expressed as the means \pm standard deviation $(p<0.05)(13)$.

\section{RESULTS AND DISCUSSION}

Little is known about propolis effects on diabetes mellitus. In the present work, glucose concentration increased significantly and continuously after STZ administration, even subsequent to propolis treatment (P10 and P90) (Figure 1 - A). Previous reports of our group revealed that propolis (100 $\mathrm{mg} / \mathrm{kg}$ ) decreased by $55 \%$ the cholesterol levels of hypercholesterolemia-induced rabbits (14). Free fatty acids were significantly decreased at the $21^{\text {st }}$ day in P10 group (Figure 1 - B).

One may see in Figure 2 (A) that no significant differences were recorded in body weight, although some variations may have occurred. One may speculate that 35 $\mathrm{mg} / \mathrm{kg}$ of STZ induces moderate diabetes, so that no influence was registered on body weight. It was observed that diabetogenic activity could be demonstrated between doses of 25 and $100 \mathrm{mg} / \mathrm{kg}$ of STZ, but doses higher than $65 \mathrm{mg} / \mathrm{kg}$ led to severe diabetes and consequently to an excessive weight loss (15). Another hypothesis that may not be discarded is whether propolis minimized a possible weight loss in animals, reducing the intensity of metabolic alterations in diabetic rats, what deserves further investigation. 
(A)

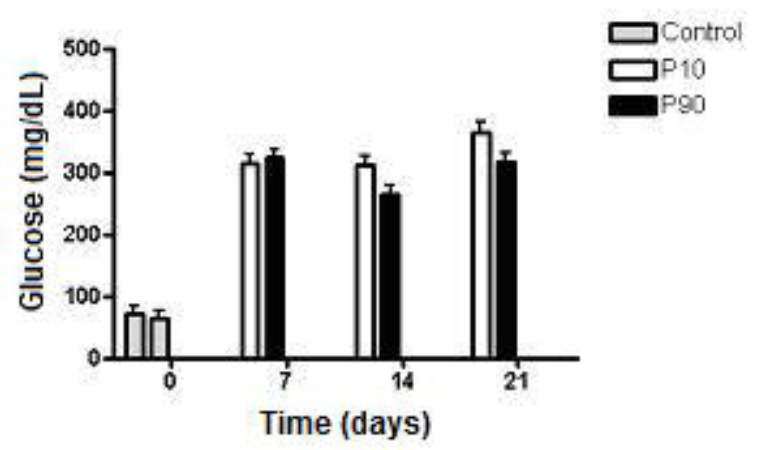

(B)

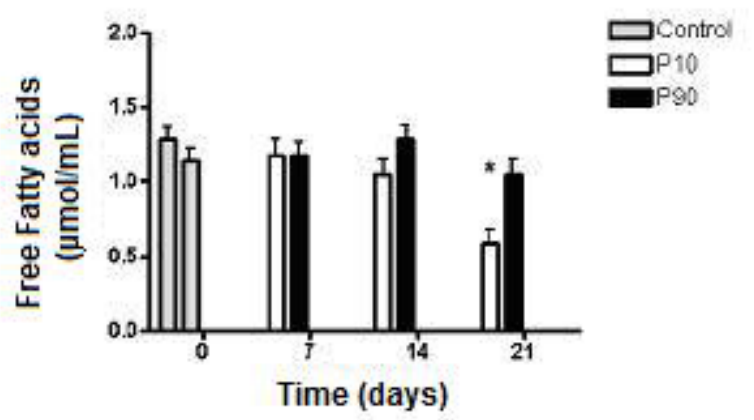

Figure 1. Glycemia (A) and free fatty acids (B) concentration of control group and propolis treated rats (P10 or $\mathrm{P} 90)$ after 7,14 and 21 days of streptozotocin administration. *Significantly different from day $0(p<0.05)$

(A)

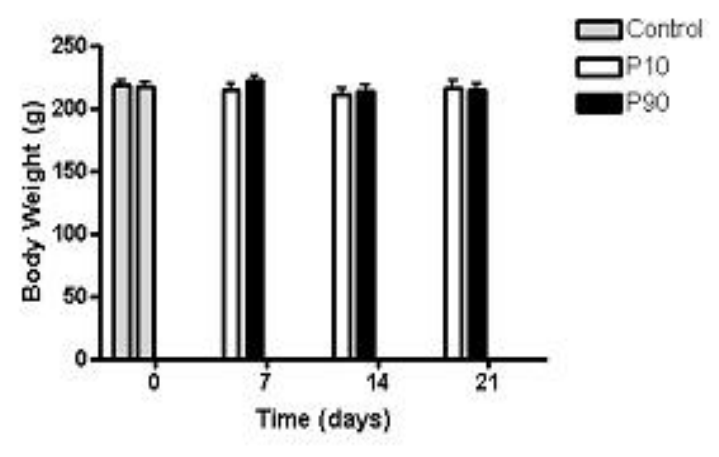

(C)

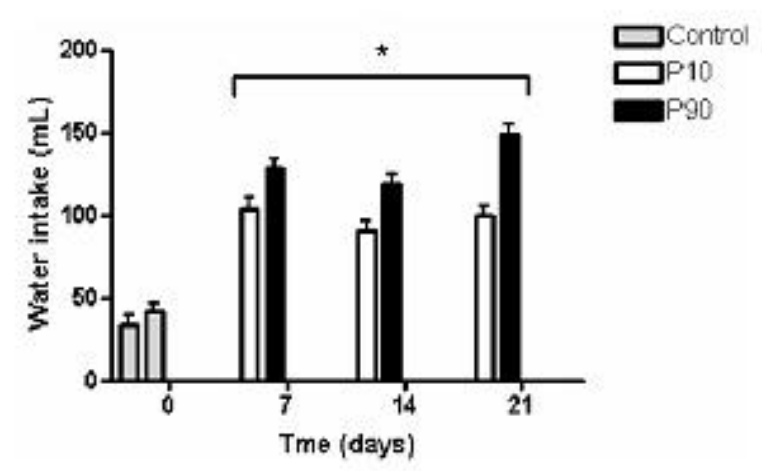

(B)

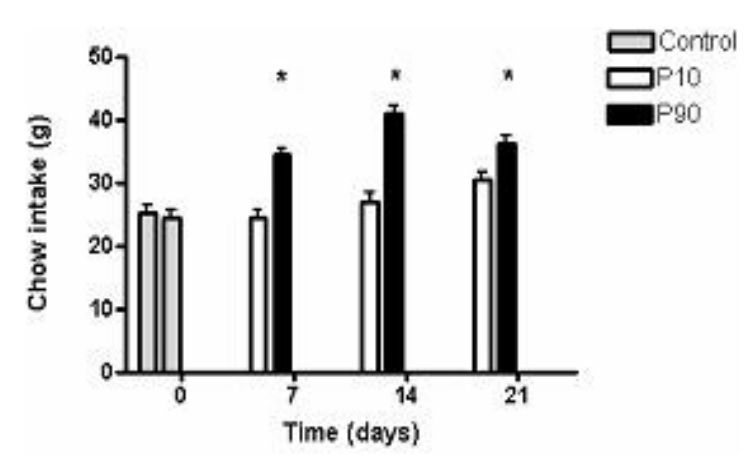

(D)

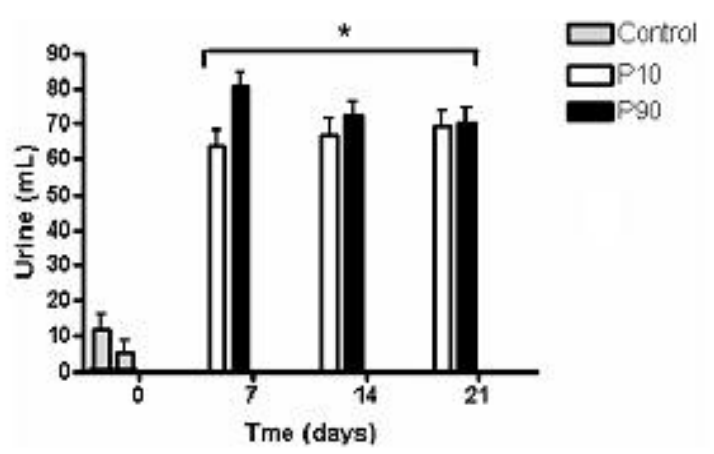

Figure 2. Body weight (A), chow intake (B), water intake (C) and urine volume (D) of control group and propolis treated rats (P10 or P90) after 7, 14 and 21 days of streptozotocin administration. *Significantly different from day $0(p<0.05)$ 
No significant difference was observed on chow intake in P10 group. On the other hand, a significant increase in chow intake was verified after treatment with $90 \mathrm{mg} / \mathrm{kg}$ of propolis (Figure $2-B$ ). A significant augment was also seen in water intake (Figure $2-\mathrm{C}$ ) and in urine volume after STZ administration to groups P10 and P90 (Figure $2-D$ ). Diuresis is one of the early symptoms of diabetes mellitus, followed by excessive water intake (5).

An estimated 150 million people suffer from diabetes mellitus across the globe. Each afflicted person is at augmented risk of developing a number of complications associated with reduction in life quality and increase in individual morbidity and mortality. However, despite these psychosocial implications, as well as the financial burden associated with the management of the disease, treatment options are costly (16).

Failure of pancreatic $\beta$-cells is the general characteristic of both diabetes types. Type 1 is induced by destruction of pancreatic $\beta$-cells, mediated by an autoimmune mechanism and consequent inflammatory process. Various inflammatory cytokines and oxidative stress are produced during this process, which has been proposed to play an important role in mediating $\beta$-cell destruction. Type 2 diabetes is the most prevalent and serious metabolic disease, and $\beta$-cell dysfunction and insulin resistance are hallmarks of this type. Under diabetic conditions, chronic hyperglycemia gradually deteriorates $\beta$-cell function and aggravates insulin resistance (17).

Cytokines including IL-1 $\beta$, TNF- $\alpha$ and IFN- $\gamma$ are able to inhibit islet function and cause islet cell death. Experimentally, the detrimental effects of STZ may be due in part to NO generation (7).

In the last years, propolis has gained popularity and researchers have tried to elucidate its effects scientifically. Bud exudates of different poplar species are the main sources of propolis in temperate zone, including Europe, Asia and North America. Samples originating from these regions are characterized by similar chemical composition. Their most important constituents appear to be phenolics: flavonoids, aromatic acids and their esters. The chemical analysis of our propolis sample, collected in the Beekeeping Section of the university, revealed that its main components are phenolic compounds (flavonoids, aromatic acids, benzopyranes), diand triterpenes, essential oils, among others. The main constituents of our propolis 
samples were isolated and identified, flavonoids are present in small quantities in Brazilian propolis (kaempferid, 5,6,7-trihydroxy-3,4'-dimethoxyflavone, aromadendrine-4'-methyl ether); a prenylated p-coumaric acid and two benzopyranes: $E$ and $Z$ 2,2-dimethyl-6-carboxyethenyl-8-prenyl-2H-benzopyranes); essential oils (spathulenol, (2Z,6E)-farnesol, benzyl benzoate and prenylated acetophenones); aromatic acids (dihydrocinnamic acid, $p$-coumaric acid, ferulic acid, caffeic acid, which are common for poplar propolis, 3,5-diprenyl-p-coumaric acid, 2,2dimethyl-6-carboxy-ethenyl-8-prenyl-2H-1-benzo-pyran); di- and triterpenes, among others. Seasonal variations in propolis composition are not significant and are predominantly quantitative (18-20).

It has been reported that the water extract of propolis $(200 \mathrm{mg} / \mathrm{kg})$ prevented $\beta$-cells destruction by inhibiting IL-1 $\beta$ generation and NO synthase activity (21). Water or ethanolic extract of propolis administration for seven weeks to STZ-induced diabetic rats decreased glucose, total cholesterol and triglycerides levels, and nitric oxide synthase activity, suggesting that propolis may control blood glucose and modulate glucose and lipid metabolism, leading to decreased outputs of lipid peroxidation and scavenging the free radicals in diabetic rats (22). It has been also reported that the eight-week treatment with caffeic acid phenethyl ester (CAPE), an active component of propolis, reduced the oxidative stress in STZ-induced diabetic rats (23). Brazilian propolis extract (100 and $300 \mathrm{mg} / \mathrm{kg}$, PO) treatment to $15 \%$ fructose-treated rats for eight weeks significantly decreased the plasma level of insulin and body weight, without affecting blood glucose and total cholesterol levels (24).

On the basis of these data, propolis did not counteract STZ effects. Propolis was administered over a short-term to animals and possibly its administration over a longterm might have been more efficient. Before establishing a strategy using this bee product, it is necessary to know under which conditions it may promote health. Further assays are necessary to investigate the ideal concentrations, period of administration and chemical composition of propolis samples, in order to explore its therapeutic potential to diabetic individuals. 


\section{CONCLUSIONS}

Ethanolic extract of propolis $(10 \mathrm{mg} / \mathrm{kg}$ and $90 \mathrm{mg} / \mathrm{kg})$ administration for seven days to STZ-induced diabetic rats did not influence the glycemia, as well as the body weight, chow and water intake, and urine volume. FFA levels were significantly decreased at the $21^{\text {st }}$ day in the group P10. However, even when some alterations were significant, it may not be attributed to propolis treatment, but to the diabetes condition.

\section{REFERENCES}

1. Sforcin JM. Propolis and the immune system: a review. J Ethnopharmacol. 2007;113(1):1-14.

2. Jasprica I, Mornar A, Debeljak Z, Smolcic-Bubalo A, Medic-Saric M, Mayer L, Romic Z, Bucan K, Balog T, Sobocanec S, Sverko V. In vivo study of propolis supplementation effects on antioxidative status and red blood cells. J Ethnopharmacol. 2007;110(3):548-54.

3. Sforcin JM, Novelli ELB, Funari SRC. Seasonal effect of Brazilian propolis on seric biochemical variables. J Venom Anim Toxins. 2002;8(2):244-54.

4. Bankova V, Boudourova-Krasteva G, Sforcin JM, Frete X, Kujumgiev A, MaimoniRodella R, Popov S. Phytochemical evidence for the plant origin of Brazilian propolis from São Paulo State. Z Naturforsch. 1999;54(5-6):401-5.

5. Brown DRN. Diabetes mellitus. Hayward (CA): Nurse Research Publication. [Internet]. [place unknown: publisher unknown]; 2002. [cited 2007 Nov. 20]. Available from: www.nurseslearning.com/courses/npr/NPR1605/course/diabetes.pdf.

6. Ganong FG. Endocrine functions of the pancreas \& regulation of carbohydrate metabolism. In: Review of Medical Physiology. 22 ed. New York: McGraw-Hill Book Company; 2005. p. 336-355.

7. Harb G, Toreson J, Dufour J, Korbutt G. Acute exposure to streptozotocin but not human proinflammatory cytokines impairs neonatal porcine islet insulin secretion in vitro but not in vivo. Xenotransplantation. 2007;14(6):580-90.

8. Konrad RJ, Mikolaenko I, Tolar JF, Liu K, Kudlow JE. The potential mechanism of the diabetogenic action of streptozotocin: inhibition of pancreatic beta-cell O-GIcNAcselective N-acetyl-beta-D-glucosaminidase. Biochem J. 2001;356(Pt1):31-41.

9. Sforcin JM, Orsi RO, Bankova V. Effect of propolis, some isolated compounds and its source plant on antibody production. J Ethnopharmacol. 2005;98(3):301-5. 
10. Cetto AA, Weidonfeld $H$, Revilla MC, Sergio IA. Hypoglycemic effect of Equisetum myriochaetum aerial parts on STZ-diabetic rats. J Ethnopharmacol. 2000;72(1/2):129-33.

11. Dole VP, Meinertz $\mathrm{H}$. Microdetermination of long-chain fatty acids in plasma and tissues. J Biol Chem. 1960;235:2595-9.

12. King EJ, Garner RJ. Colorimetric determination of glucose. J Clin Phatol. 1947;1(1):30-3.

13. Zar JH. Biostatistical analysis. $4^{\text {th }}$ ed. New Jersey: Pretince Hall; 1999. 663 p.

14. Boudourova-Krasteva G, Bankova V, Sforcin JM, Nikolova N, Popov S. Phenolics from Brazilian propolis. Z Naturforsch. 1997;52c:676-9.

15. Junod A, Lambert AE, Stauffacher W, Renold AE. Diabetogenic action of streptozotocin: relationship of dose to metabolic response. J Clin Invest. 1969;48(11):2129-39.

16. Leach MJ. Gymnema sylvestre for diabetes mellitus: a systematic review. J Altern Complement Med. 2007;13(9):977-84.

17. Kaneto H, Matsuoka TA, Katakami N, Kawamori D, Miyatsuka T, Yoshiuchi K, Yasuda T, Sakamoto K, Yamasaki Y, Matsuhisa M. Oxidative stress and the JNK pathway are involved in the development of type 1 and type 2 diabetes. Curr Mol Med. 2007;7(7):674-86.

18. Bankova V, Boudourova-Krasteva G, Popov S, Sforcin JM, Funari SRC. Seasonal variations in essential oil from Brazilian propolis. J Essent Oil Res. 1998a;10:693-6.

19. Bankova V, Boudourova-Krasteva G, Popov S, Sforcin JM, Funari SRC. Seasonal variations of the chemical composition of Brazilian propolis. Apidologie. 1998b;29:361-7.

20. Fernandes AAH, Alves MJF, Boteon EM, Rosa GJM, Silva CEF. Avaliação do colesterol plasmático em coelhos com hipercolesterolemia induzida e tratados com extrato etanólico de própolis. Rev Bras Plantas Medicinais. 2002;4:1-5.

21. Matsushige K, Basnet P, Hase K, Kodota S, Tanaka K, Namba T. Propolis protects pancreatic $\beta$-cells against the toxicity of streptozotocin (STZ). Phytomedicine. 1996;3:203-9. 
22. Fuliang HU, Hepburn HR, Xuan H, Chen M, Daya S, Radloff SE. Effects of propolis on blood glucose, blood lipid and free radicals in rats with diabetes mellitus. Pharmacol Res. 2005;51(2):147-52.

23. Okutan H, Ozcelik N, Yilmaz HR, Uz E. Effects of caffeic acid phenethyl ester on lipid peroxidation and antioxidant enzymes in diabetic rat heart. Clin Biochem. 2005;38(2):191-6.

24. Zamami Y, Takatori S, Koyama T, Goda M, Iwatani Y, Doi S, Kawasaki H. Effect of propolis on insulin resistance in fructose-drinking rats. Yakugaku Zasshi. 2007;127(12):2065-73. 